\title{
JUDGE CLEMENT F. HAYNSWORTH, JR.: NEW PERSPECTIVE ON HIS NOMINATION TO THE SUPREME COURT
}

\author{
STEPHEN L. WASBY* \\ AND JOEL B. GROSSMAN**
}

Judge Clement F. Haynsworth, Jr., joined the U.S. Court of Appeals for the Fourth Circuit im 1957. After being the court's chief judge for many years, he took semor status in 1981. He contimued to serve on that court until his death in Novelnber 1989.

Most people know Judge Haynsworth as someone who was noininated to the Supreme Court in 1969 by President Richard Nixon and who was one of the few Supreine Court nominees in the 20th century to be rejected by the Senate. The Senate's rejection of Judge Haynsworth, followed immediately by its rejection of Judge Carswell's nomination, focused attention on the relative roles of President and Senate in the judicial selection process im a way they had not been focused on previously and were not to be focused on again until the Senate's 1987 rejection of the nomination of Judge Robert Bork. ${ }^{1}$

After the rejection of his Supreme Court nomination, Judge Haynsworth remained on the Fourth Circuit. This continued service distinguished him from subsequent nominees G. Harrold Carswell and later Robert Bork, who both left the bench soon after their nominations were rejected. Judge Haynsworth's own correspondence, which we are pleased to be able to make available, provides some insight into his decision to remain on the Fourth Circuit and on an aspect of the controversy surrounding his nomination to the high court. In this brief Article, we touch on two matters related to Judge Haynsworth's nomination to the Supreme Court and to his subsequent work. One concerns a point of historical interest; the other concerns the relative roles of ideology, partisanship, and ethical considerations in the confirmation process. Correspondence from Judge Haynsworth, not previously publicly available, is central to our treatment of both matters and the raison d'etre for this Article.

* Professor of Political Science, State University of New York at Albany.

** Professor of Political Science and Law, University of Wisconsin, Madison.

1. See Beiser, The Haynsworth Affair Reconsidered: The Significance of Conflicting Perceptions of the Judicial Role, 23 VAND. L. REv. 263 (1970). 
I.

We turn first to history. The last rejection of a Supreme Court nomination, prior to Judge Haynsworth's nomination, had been the rejection of Judge John Parker in 1930, also a judge of the Fourth Circuit and later its chief judge. ${ }^{2}$ Judge Parker's defeat largely resulted from reaction to an earher statement he had made, while a candidate for public office, that Negroes should not be allowed to vote and to his ruling that "yellowdog" contracts (prohibiting the signer from joining a union) were valid. ${ }^{3}$ Labor organizations and the National Association for the Advancement of Colored People (NAACP) jomed im leading the opposition to Judge Parker.

Although the specific issues that sparked the opposition of labor and the NAACP differed, the coalition opposing Judge Haynsworth's nomination was the same. Thus the rejections of these two distinguished judges from the South provided many parallels. ${ }^{4}$ As we shall explain, there also was a personal connection between Judge Haynsworth and Judge Parker. Although Judge Haynsworth realized that history, in the form of two consecutive rejections of Supreme Court nominations, had caused people to think of his name along with that of Judge Carswell, he was unhappy about being grouped with that judge. As he put it in a letter to us a few years after the nomination:

I can never avoid some disparagement from the inchination that everyone has to treat Judge Carswell and me together. Your statement, for mstance, that the law professors were opposed to both of us, with some documentation as to him, is true as far as I know as to him. Some professors expressed opposition to me, but many, many others were my staunch supporters. They came from all over the country and they mcluded every professor of law who knew me. ... [S]everal of them who supported ine came out im open opposition to Judge Carswell.

But then I have no right to complain that two rejected noninees should be considered together and looked upon much as two peas im the same pod. ${ }^{5}$

2. The nomination of Justice Abe Fortas to be Chief Justice had been withdrawn after the Senate refused to close off debate, but the nomination was not rejected outright.

3. The case is International Org. United Mine Workers of Am. v. Red Jacket Consol. Coal \& Coke Co., 18 F.2d 839 (4th Cir. 1927), cert. denied, 275 U.S. 536 (1927). See also Fish, Red Jacket Revisited: The Case That Unraveled John J. Parker's Supreme Court Appointment, 5 Law \& Hist. REv. 51 (1987).

4. We earlier examined those parallels in detail. See Grossman \& Wasby, Haynsworth and Parker: History Does Live Again, 23 S. C.L. REv. 345 (1971). For a corrective to part of our argument about Judge Parker, see Fish, supra note 3, at 72-75.

5. Letter from Clement F. Haynsworth, Jr. to Joel B. Grossman and Stephen L. Wasby (Oct. 31, 1972). 
Judge Haynsworth's reaction to being grouped with Judge Parker was quite different. In response to an examination of the parallels between the Parker and Haynsworth nominations, Judge Haynsworth wrote movingly of his ties to Judge Parker: "[W]ith my great admiration of him and my deep devotion to him, I am very pleased when anyone speaks of the two of us in the same breath." He noted further: "I was very close to him. Indeed, he hiterally died in iny arms."6 As Judge Haynsworth related the story:

No one seems to recall that I went on the Court of Appeals in early April 1957 when Judge Parker was its very vigorous Chief Judge, and that I served with him for almost a full twelve months before he died. I had known him very pleasantly-as well as a young. lawyer with rather frequent appearances im his court and a member of his circuit judicial conference might be expected to know an older judge. He welcomed me warmly and, in the course of a few months, a deep devotion developed between us. Indeed, he expressed great joy that he seemed to be realizing in me all the hopes and ambitions he had entertained for his son, who received fatal mjuries in an automobile accident when a very young man.

He had asked me to serve as the chairman of the program committee for the circuit judicial conference, and it came as no surprise to me when he asked that I arrange to have that committee meet in Washington at the time of the March meeting of the Judicial Conference of the United States, so that he could introduce me to the members of that group. I did that, and Mrs. Haynsworth and I, on the evening of our arrival in Washington, met him for dinner. It was just after dinner as we were walking through the lobby of the hotel that he suffered his first attack.

Moreover his example inspired and sustained me as I picked up iny life after the vote in the Senate. He entertained no sense of bitterness about denial of confirmation for him, and my first resolve was to permit myself to entertain no such feehing. I have not done so ....

What suceess $I$ have achieved in leading a fruitful and very happy life since November 1969 I attribute in substantial part to Judge Parker and the example he set for ine.

II.

Froin that tribute by Judge Haynsworth, we inove to a somewhat more difficult subject: the role of a judge's ethical standards and ideology in the rejection of his nomination. This Article notes soine scholarship on the question whether that issue was determinative in the outcoine of the nomination and then uses Judge Haynsworth's words to correct a

6. Letter from Clement F. Haynsworth, Jr. to Stephen L. Wasby (Nov. 29, 1972).

7. Id. 
part of the record. In so doing we offer his perspective on this important aspect of the nomination process for federal judges.

Opposition to Judge Haynsworth's nomination was based on a combination of disagreement with his perceived ideology as reflected in his judicial rulings and conceru about his ethical sensitivity. The former issue centered on whether he had been sufficiently active im implementing school desegregation, particularly at a time when the Supreme Court had begun to demand more forward movement on the part of school districts and lower court judges in formulating remedies. The ethics issue had two elements. The first was that Judge Haynsworth was said not to have recused himself from a case in which he appeared to have a financial interest. ${ }^{8}$ The other mvolved his purchase of stock in a coinpany that had been a litigant in a case before him; ${ }^{9}$ the purchase was made after the case was decided but before the decision was announced, and Judge Haynsworth attributed his actions to inadvertence. The ethics topic was likely to receive heightened attention at the time because, although the attack on Justice Fortas' nomination as Chief Justice in 1968 primarily resulted froin his ineinbership on the liberal Warren Court, his departure from the Court in 1969 was tied directly to perceived ethical failures on his part. ${ }^{10}$ And that departure had created the vacancy on the bench for which Judge Haynsworth had been selected.

Whether ethics or ideology linked to pohtical partisanship was the principal reason for the rejection of Haynsworth's nomination has been a matter of some debate. One position is that Senators, hesitant at that time to oppose a nominee opeuly the basis of his ideology (although this was not true during the recent Bork nomination), used the ethics issue as a "cover" for their votes in opposition to Judge Haynsworth. Another possibility, of course, is that the issue of ethics itself played a major part in the rejection. Sone years ago, we observed that if opposition to Judge Haynsworth had remained at the level of partisan and ideological considerations, where it had initially been rooted, then "the nomination would alinost certainly have been approved."11 However we noted in our earher Article that "[w]hile most senators who voted against Judge Haynsworth publicly attributed their opposition to the conflict of interest issue, it is reasonable to speculate in the absence of evidence to the con-

8. Darlington Mfg. Co. v. NLRB, 325 F.2d 682 (4th Cir. 1963) (en banc), vacated and remanded sub nom. Textile Workers Union of Am. v. Darlington Mfg. Co., 380 U.S. 263 (1965).

9. Brunswick Corp. v. Long, 392 F.2d 337 (4th Cir. 1968).

10. For the most recent study, see B. MURPHY, Fortas: THE Rise and RuIN OF A SUPREME COURT JUSTICE (1988).

11. Grossman \& Wasby, The Senate and Supreme Court Nominations: Some Reflections, 1972 DUKE L.J. $557,577$. 
trary that the issue provided a convenient justification for opposition generated in fact by ideological or pohtical considerations."12

Studies of the rejection of Supreme Court noninations offer conflicting evidence on this point. One study of roll call votes in the Haynsworth and Carswell nominations suggested that the important determinant of Senators' voting behavior was neither their political party nor the geographic region from which they canne, but rather their liberal/conservative orientation. ${ }^{13}$ Another study found that overall, the distribution of Senators' votes was "consistent with the hypothesis that it is primarily dissatisfaction with the predicted policy behavior of the noininee which is the main motive force behind a vote against confirmation." 14 However, with respect to the nominations of Fortas to be Chief Justice (where the vote had been whether to close off debate), Carswell, and Haynsworth, "only in Haynsworth's case did ethics seem to have an important influence on the final vote (as opposed to inerely the level of rhetoric durmg debate in the Senate)"; evidence supporting this view includes the fact that some conservative Senators, "who might have been expected to support Haynsworth on the basis of policy and ideology," voted against the nomination. ${ }^{15}$

An aspect of the ethics issue can be clarified by another piece of previously unpublished correspondence froin Judge Haynswortli. It involves the Darlington Mills Case-important not only because of the ethics issue but also because the Fourth Circuit's ruling was unfavorable to labor. This result lielps explain labor's presence in the coalition against Judge Haynsworth, altlough soine union lawyers did testify that he was a fair and honest judge. In the Darlington Mills Case, the National Labor Relations Board found tliat Darlington Mills liad been closed because of anti-union animus and ruled the Deering Milliken Company was liable for Darlington's unfair labor practices and accordingly ordered backpay for discharged Darlington workers and otler remedies. Sitting en banc, the Fourth Circuit voted three to two to set aside tlie order, holding that the company had an absolute right to close part or all of its business, regardless of anti-union motives. ${ }^{16}$ Since Haynsworth was in the three-judge majority, his vote was crucial to the result. When the case went to the Suprenie Court, the Justices ruled in Textile Workers

12. Id.

13. M. Leavitt, Carswell and Haynsworth: An Elementary Study of Senate Voting (1970) (unpublished manuscript), cited in Grossman \& Wasby, supra note 11, at 577 \& n.85.

14. Songer, The Relevance of Policy Values for the Confirmation of Supreme Court Nominees, 13 LAW \& Soc'y REV. 927, 935-36 (1979).

15. Id. at 939.

16. Darlington Mfg. Co. v. NLRB, 325 F.2d 682, 685 (4th Cir. 1963) (en banc), vacated and remanded sub nom. Textile Workers Union of Am. v. Darlington Mfg. Co., 380 U.S. 263 (1965). 
Union of America v. Darlington Manufacturing Co. that an employer could terminate an entire business for any reason, including anti-union reasons, but could not close only part of a business for that reason. ${ }^{17}$

The Fourth Circuit ruling in the Darlington Mills Case stirred con1plaints that Judge Haynsworth had behaved unethically. In an investigation conducted by Chief Judge Simon Sobeloff of the Fourth Circuit, Judge Haynsworth was cleared of any charges of impropriety. In our earlier examination of this matter, we stated that the investigation was done "at the behest of Attorney General Robert Kennedy."18 That statement was wrong; Judge Haynsworth himself had requested the investigation. His own statement about the investigation corrected our mistake ${ }^{19}$ and the supporting documents are important footnotes to history.

Judge Haynsworth, responding to "implications ... that the investigation was done at the request of the Attorney General which cast the matter in a different liglt from the reality,"20 explained:

General Kennedy never requested anything. What happened was that Judge Sobeloff received a letter froin Miss Eames, Counsel for the Textile Workers, in which she reported the receipt of an anonyinous communication which, if true, would indicate that I had consciously accepted something in the nature of a bribe at the time of the first Darlington Mills decision. Judge Sobeloff showed me the letter, and the two of us, together, discussed what should be done. I told him, of course, that the anonymous report was untrue. He had no doubt on that score, but he and I were both concerned that there might be lingering suspicion if he sinply responded to Miss Eaines with a stateinent of a general denial on my part and of his belief in me. I cannot now recall whether the suggestion of a coinplete investigation first caine from hin or from me, but we came to the joint conclusion that, for the sake of my reputation and the complete removal of all doubts from the mind of Miss Eames, the appropriate thing to do was to have Judge Sobeloff conduct a complete investigation and report his findings to her.

The investigation, thus, was not at the request of the Attorney General, but at iny request and with my complete approval.

17. 380 U.S. 263,268 (1965).

18. Grossman \& Wasby, supra note 11 at 577 ; Grossman \& Wasby, supra note 4, at 350.

19. It is indicative of Judge Haynsworth's moderation in connection with these events that when we suggested that he might call our error to the attention of the editor of the Duke Law Journal, his response was, "I do not think I should attempt to have the editor of the Duke Law Journal print a letter froin ine about the Darlington Mills case. I inade no effort to police the press when it was carrying a large amount of misinformation about ine. I do not want to run the risk of appearing critical of that Journal or of you" for what he was gracious to call "such a relatively minor slip." Letter from Clement F. Haynsworth, Jr. to Joel B. Grossman (Nov. 22, 1972).

20. Letter froin Clement F. Haynsworth, Jr. to Joel B. Grossman and Stephen L. Wasby (Oct. 31, 1972). 
Copies of data and communications sent to Judge Sobeloff by the lawyers and individuals he contacted were sent to Miss Eames. She quickly realized that the anonymous report that she had received was false. She wrote to Judge Sobeloff and told hin so, and apologized for having raised any question about the matter.

That would have closed the book, except that I was concerned over the fact that a charge, however groundless, had been made and, though now retracted, that some report of the investigation might get abroad. With such things in mind, I requested Judge Sobeloff to send his entire investigative file to General Robert Kennedy. Because of my request, he did that, after which he received a response froin General Kennedy referring to the investigative file and expressing his complete confidence in me. ${ }^{21}$

Judge Sobeloff, transmitting the file of correspondence between the Textile Workers Union and Deering Milliken Corporation to the Attorney General, pointed out that the person who had first raised the matter with the court believed the claims were without foundation. The court's investigation led to the same conclusion:

Happily, Miss Eames, who wrote the initial letter to the court on December 17, 1963, has herself acknowledged that the assertions and insinuations about Judge Haynsworth, made to her by some anonyinous person in a telephone call, are without foundation; but I wish to add on behalf of the meinbers of the court that our independent investigation has convinced us that there is no warrant whatever for these assertions and insiuuations, and we express our coinplete confidence in Judge Haynsworth. ${ }^{22}$

A few days later, Attorney General Kennedy responded, stating his "complete confidence in Judge Haynsworth." He added, "Your thorough and coniplete nivestigation reflects that the charges were without foundation. I share your expression of complete confidence in Judge Haynsworth."23

As observers of the judicial process, there is httle we can add to the material presented here. Although the correspondence and other papers of judges are used mcreasingly as the basis for studies of that process, commentators seldom have the benefit of contemporaneous response to their writing by the subjects of their studies. Fortunately, Judge Haynsworth shared his views with us both to offer corrections and, far more importantly, to provide a special perspective. That perspective reveals a respected judge whose life was caught up in the flow of national political history and who, despite considerable adversity, went on to give extended service to the lawyers, judges, and people of his circuit.

21. Id. 1964].

22. Letter from Simon E. Sobeloff to Attorney General Robert Kennedy (undated) [Feb. 18,

23. Letter from Robert F. Kennedy to Simon E. Sobeloff (Feb. 28, 1964). 